\title{
Assessment of heavy metals in body muscles/organs of locally reared poultry in cocoa and non-cocoa producing areas of Cross River State, Nigeria
}

\author{
Williams, Mary Emmanuel ${ }^{1 *}$, Igile, Godwin $0 .^{2}$, Usoro, Ofoninyene Okon ${ }^{1}$ and Offiong, Edem ${ }^{1}$ \\ 1Department of Animal Science, Akwa Ibom State University, P.M.B. 1167, Uyo, Nigeria. \\ ${ }^{2}$ Department of Biochemistry, University of Calabar, Calabar. Nigeria. \\ *Corresponding author. Email: mw189742@gmail.com. Tel: +234 8034062727.
}

Copyright @ 2017 Williams et al. This article remains permanently open access under the terms of the Creative Commons Attribution License 4.0, which permits unrestricted use, distribution, and reproduction in any medium, provided the original work is properly cited.

Received 20th March, 2017; Accepted 11th May, 2017

\begin{abstract}
There is a growing concern about the impact of increased used of Agro-pesticide on public health and safety issues especially in farming community who pursue high agricultural productivity. Pesticide pollution is a subject of global concern and the extent of its poisoning is considered to be grossly under estimated. This study was conducted to assess the concentration of heavy metals $(\mathrm{Cd}, \mathrm{Pb}, \mathrm{Hg}, \mathrm{Cr}$, As and $\mathrm{Ni}$ ) in muscle, liver, kidney and lungs of matured locally reared chickens. Sampling was carried out in two cocoa producing areas (Ikom and Etung) and non-cocoa producing area (Odukpani) in Cross River State, Nigeria, over a period of one year (November, 2013 to October, 2014). Determination of heavy metals was carried out using Atomic Absorption Spectrophotometer (ASS). Highest levels of cadmium $(0.11 \pm 0.02 \mu \mathrm{g} / \mathrm{g})$ and lead $(0.26 \pm 0.11 \mu \mathrm{g} / \mathrm{g})$ were recorded in liver simples from Etung and lkom. The highest levels of chromium concentration $(2.95 \pm 0.05 \mu \mathrm{g} / \mathrm{g}$ ) was observed in kidney of chickens from Etung, while nickel (1.16$\pm 0.0404 \mu \mathrm{g} / \mathrm{g}$ ) was highest in lung samples from Etung and Odukpani recorded the highest nickel concentration values $(1.16 \pm 0.04 \mu \mathrm{g} / \mathrm{g})$. The results show that higher levels of heavy metals can accumulate in the body tissues/organs of chickens in cocoa producing area. These are no exception since Etung is a cocoa producing area and the metals were found highest in kidney and lungs of chicken from this area. Generally, livers and kidneys were found to have the highly significant $(P<0.5)$ levels of the metals than the muscles and lungs the lowest. However, the concentrations of all the metals studied were within the tolerance limits with exception of chromium and nickel which were respectively higher than their $0.10 \mu \mathrm{g} / \mathrm{g}$ and $0.5 \mu \mathrm{g} / \mathrm{g}$ tolerance limit. The results obtained in this study will be useful in formulating guidelines and standards for heavy metals in chicken products in cocoa-producing and non-cocoa producing areas of Nigeria.
\end{abstract}

Key words: Bio-accumulation, local chicken, organs, tissues.

\section{INTRODUCTION}

Cocoa business includes cocoa farming, cocoa seed processing, warehousing and export. This cocoa value chain processes is sustained with the application of various pesticides right from (pre and post-harvest) inception of cocoa industry in Nigeria, including cocoa producing areas of Cross River State. Unsafe use of pesticides has been shown by various studies to be detrimental to livestock, environment and particularly the food chain including crops, man and other animals. Unregulated use of pesticides can generates persistent organic pollutants (POPS) and leaves pesticide residues in the environment (Asogwa and Dongo, 2009).
Most pesticides contain heavy metals including those of global concern such as mercury $(\mathrm{Hg})$, cadmium $(\mathrm{Cd})$ and chromium ( $\mathrm{Cr})$. Others include lead (Pb), Arsenic (As) and Iron ( $\mathrm{Fe})$. These heavy metals are generally known to elicit deleterious metabolic and endocrine response in man and animals and also interact adversely with mineral element to reduce their bioavailability in human nutrition (Johnson, 2004). Baykov et al. (1996) and Demirezen and Uruc (2006) indicated that contamination with heavy metals is a severe health hazard since they are toxic, bio accumulates and biomagnify in the food chain. Furthermore, the accumulation of heavy metals varies 
significantly from one tissue to another within an animal and varies also between one animal to another (John and Jeanne, 1994).

The human population in cocoa growing areas of Cross River State including Ikom and Etung Local Government Areas is in the rural, low income and food insecure areas. Family poultry production especially the indigenous chickens play a significant role in the economic and social life of these resourceful poor household. Thus, rearing local chickens contributed to cheap source of animal protein intake and family income (Magothe et al., 2012). The scavenging nature of rearing family poultry (indigenous chickens) in cocoa growing areas of Cross River State exposes not only chickens but also other livestock to some toxic chemical substances $(\mathrm{Hg}, \mathrm{Cd}, \mathrm{As}$, $\mathrm{Pb}$ etc) and other persistent organic pollutants (POPs) resulting from the use of pesticides in cocoa plantations. Johnson (2004) reported that, apart from bioaccumulation and bio-magnification of heavy metals from pesticides, it also exerts acute and chronic toxic effect on non-target organism in the ecosystem.

There is paucity of information on the status of pesticides residues and bio-accumulation levels in avian species, livestock and wildlife in cocoa producing areas of Nigeria. This study was carried out to assess the accumulation levels of heavy metals in body tissue and organs of family poultry locally reared chickens in cocoa producing and non-coca producing areas of Cross River State.

\section{MATERIALS AND METHODS}

\section{Collection of sample}

Fresh Samples (thirty per location) of breast muscles, liver, kidney and lungs of local chickens were collected from various locations of cocoa producing areas of Ikom and Etung Areas and non-cocoa producing area of Odukpani in Cross River State between the period of November, 2013 and October, 2014. A total of two hundred and seventy (270) adult unsexed chicken were used and slaughtering process were not considered as factors in heavy metal concentration in the chicken muscles and organs. Identified volunteered households at different experimental sites were randomly selected. This was done based on the level of protection that was offered by the farmers in monitoring the birds. The birds were wing banded for easy identification, housed cages and fed commercial grower mash for two weeks to enable them adapt to their new environment. Thereafter, they were released for free range extensive poultry management

\section{Sample preparation and digestion}

Procedure for sample preparation in this study was adopted from Belton (2006). The collected tissue and organs were cleaned and packed in polyethylene bags and transported for analyses to the Analytical laboratory, Department of Chemistry, University of Calabar, Nigeria. The collected tissues and organs were cleaned and washed with demineralized water. The wet digestion procedure was used. $5.0 \mathrm{~g}$ of each sample (muscle, kidney, liver and lungs) was introduced into the digestion flask. $10 \mathrm{ml}$ of concentrated sulphuric acid was added to the sample and the content of digestion flask heated at $70^{\circ} \mathrm{C}$ for $3 \mathrm{hrs}$ with occasional swirling at 3 minutes interval. After complete digestion, the digest was allowed to cool and then transferred into a $20 \mathrm{ml}$ standard flask with de-ionized water. The solution were transferred into acid-leached polyethylene bottles and kept at room temperature until analysis with atomic absorption spectroscopy (AAS). Heavy metals were analyzed by using varian atomic absorption spectrophometer model 1275 AA equipped with lamps for different elements. Standard working solutions and standard curves were prepared. The standard curve for each metal was plotted and the amounts of metal present in the study samples were calculated from the standard curve.

\section{Statistical analysis}

All data collected from chemical analysis were subjected to a two-way analysis variance using a $2 \times 2$ factorial format in which heavy metals and location were factors in a completely randomized designed (SPSS, 1999). Mean separation was carried out where significant differences exist using Ducan Multiple Range Test (Duncan, 1980).

\section{RESULTS AND DISCUSSION}

The concentration of heavy metals in the muscles and organs of local chickens recorded in this study are presented in Tables 1 and 2.

\section{Cadmium (Cd)}

The results show that cadmium $(\mathrm{Cd})$ concentration was significantly higher in the muscles $(0.10 \mu \mathrm{g} / \mathrm{g})$ and livers $(0.11 \mu \mathrm{g} / \mathrm{g})$ of local chicken from Ikom and Etung Local Government areas than those obtained in Odukpani. The higher values of Cadmium in tissues and organs of chickens in cocoa areas could be attributed to deliberate and consistent application of pesticides for pest control in cocoa plantation. Persistent accumulation of pesticides residue in the plantation could result in Cadmium level found in tissue and organs in this study comparable to the levels reported by Akan et al. (2010) for local chickens and González-Weller et al. (2006). Mariam et al. (2004) reported higher cadmium content $(0.49 \mu \mathrm{g} / \mathrm{g})$ in liver and $0.31 \mu \mathrm{g} / \mathrm{g}$ in muscles of local chicken (lean meat). These results also agree with the report of Iwegbue et al. (2008), who recorded a higher cadmium 
Table 1. Heavy metals concentrations $(\mu \mathrm{g} / \mathrm{g})$ in muscle, liver, kidney and lungs of local chicken in lkom cocoa producing area of Cross River State.

\begin{tabular}{|c|c|c|c|c|c|c|c|c|}
\hline \multirow{2}{*}{$\begin{array}{l}\text { Heavy metal } \\
(\mu \mathrm{g} / \mathrm{g})\end{array}$} & Muscle & Liver & Kidney & Lungs & Muscle & Liver & Kidney & Lungs \\
\hline & \multicolumn{4}{|c|}{ Cocoa-producing area (Etung) } & \multicolumn{4}{|c|}{ Non cocoa producing area } \\
\hline Cadmium & $0.10 \pm 0.01^{c}$ & $0.11 \pm 0.02^{c}$ & $0.07^{d}$ & $0.06 \pm 0.01^{c}$ & $0.02 \pm 0.01^{c}$ & $0.04 \pm 0.01^{c}$ & $0.05 \pm 0.01^{d}$ & $0.03 \pm 0.01^{\mathrm{c}}$ \\
\hline Lead & $0.21 \pm 0.07^{b}$ & $0.22 \pm 0.11^{c}$ & $0.25^{c}$ & $0.21 \pm 0.05^{\mathrm{b}}$ & $0.18 \pm 0.06^{b}$ & $0.20 \pm 0.06^{b}$ & $0.21 \pm 0.02^{c}$ & $0.14 \pm 0.05^{b}$ \\
\hline Mercury & $0.05 \pm 0.02^{d}$ & $0.04 \pm 0.03^{d}$ & $0.06^{d}$ & $0.02 \pm 0.01^{d}$ & $0.01 \pm 0.02^{c}$ & $0.02 \pm 0.01^{d}$ & $0.02 \pm 0.01^{c}$ & $0.02 \pm 0.01^{c}$ \\
\hline Chromium & $1.01 \pm 0.02^{\mathrm{a}}$ & $1.81 \pm 0.5^{a}$ & $2.95^{a}$ & $1.20 \pm 0.07^{a}$ & $1.87 \pm 0.06^{a}$ & $1.21 \pm 0.05^{a}$ & $1.84 \pm 0.11^{\mathrm{a}}$ & $1.17 \pm 0.05^{a}$ \\
\hline Arsenic & $0.05 \pm 0.01^{d}$ & $0.02 \pm 0.02^{d}$ & $0.05^{d}$ & $0.01 \pm 0.00^{d}$ & $0.05 \pm 0.01^{c}$ & $0.02 \pm 0.01^{c}$ & $0.04 \pm 0.02^{d}$ & $0.01 \pm 0.00^{c}$ \\
\hline \multirow[t]{2}{*}{ Nickel } & $1.05 \pm 0.01^{a}$ & $1.03 \pm 0.01^{b}$ & $1.05 \pm 0.02^{b}$ & $1.16 \pm 0.04^{a}$ & $1.05 \pm 0.01^{a}$ & $1.12 \pm 0.01^{a}$ & $1.04 \pm 0.02^{b}$ & $1.16 \pm 0.04^{a}$ \\
\hline & \multicolumn{4}{|c|}{ Cocoa-producing area (lkom) } & \multicolumn{4}{|c|}{ Non cocoa producing area } \\
\hline Cadmium & $0.10 \pm 0.01^{c}$ & $0.10 \pm 0.02^{c}$ & $0.07 \pm 0.01^{c}$ & $0.07 \pm 0.01^{c}$ & $0.02 \pm 0.01^{c}$ & $0.04 \pm 0.01^{c}$ & $0.05 \pm 0.01^{d}$ & $0.03 \pm 0.01^{\mathrm{c}}$ \\
\hline Lead & $0.21 \pm 0.05^{b}$ & $0.26 \pm 0.11^{b}$ & $0.25 \pm 0.02^{b}$ & $0.24 \pm 0.05^{b}$ & $0.18 \pm 0.06^{b}$ & $0.20 \pm 0.06^{b}$ & $0.21 \pm 0.02^{c}$ & $0.14 \pm 0.05^{b}$ \\
\hline Mercury & $0.03 \pm 0.02^{d}$ & $0.03 \pm 0.01^{d}$ & $0.03 \pm 0.01^{d}$ & $0.02 \pm 0.01^{d}$ & $0.01 \pm 0.02^{c}$ & $0.02 \pm 0.01^{d}$ & $0.02 \pm 0.01^{c}$ & $0.02 \pm 0.01^{\mathrm{c}}$ \\
\hline Chromium & $1.05 \pm 0.03^{a}$ & $1.25 \pm 0.05^{\mathrm{a}}$ & $2.11 \pm 0.07^{a}$ & $1.52 \pm 0.03^{a}$ & $1.87 \pm 0.06^{a}$ & $1.21 \pm 0.05^{\mathrm{a}}$ & $1.84 \pm 0.11^{\mathrm{a}}$ & $1.17 \pm 0.05^{a}$ \\
\hline Arsenic & $0.02 \pm 0.01^{d}$ & $0.03 \pm 0.02^{d}$ & $0.04 \pm 0.02^{d}$ & $0.01 \pm 0.00^{d}$ & $0.05 \pm 0.01^{c}$ & $0.02 \pm 0.01^{c}$ & $0.04 \pm 0.02^{d}$ & $0.01 \pm 0.00^{c}$ \\
\hline Nickel & $1.13 \pm 0.01^{\mathrm{a}}$ & $1.13 \pm 0.22^{\mathrm{a}}$ & $1.05 \pm 0.01^{\mathrm{a}}$ & $1.15 \pm 0.04^{\mathrm{a}}$ & $1.05 \pm 0.01^{\mathrm{a}}$ & $1.12 \pm 0.01^{a}$ & $1.04 \pm 0.02^{b}$ & $1.16 \pm 0.04^{\mathrm{a}}$ \\
\hline
\end{tabular}

abc Means with different superscripts along the same column are significantly different $(P<0.05)$.

concentration level in the liver of turkey. Doganoc (1996) reported a higher level of cadmium and zinc in the liver and kidney of hens which exceeded the permissible limit of $0.5 \mathrm{ppm}$ set by FAO/WHO (2000). Cadmium is known to be toxic to almost every system in the body (Lee et al., 2006). Baykov et al. (1996) reported that feed is one of the principal environmental sources of cadmium in poultry. The higher concentration of cadmium in the liver of local chicken in the cocoa producing areas could be attributed to detoxification function of the organ where toxic substances get accumulated.

Cadmium concentration in the kidney and liver over long time could interact with a number of minerals such as zinc, iron, copper and sodium due to chemical similarities and competition for bounding site (Aranha, 1994 and Stoyke et al., 1995). In addition cadmium can replace Calcium in the bone structure making the bone to lose it rigidity and become porous. A condition observed in Itai-Itai syndrome.

Roga-Franc et al. (1996) also observed cadmium levels in the livers and kidneys of cattle in Poland and found its concentration to be above the permissible limit recommended by FAO/WHO (2000). Cadmium concentrations in all the samples studied were lower than $0.5 \mathrm{ppm}$ limit by FAO/WHO (2000).

\section{Lead $(\mathrm{Pb})$}

The livers and kidneys of local chickens in Ikom and Etung cocoa producing areas recorded higher lead concentration levels compared to Odukpani, a non-cocoa producing area. The highest lead concentration was found in liver $(0.26 \mu \mathrm{g} / \mathrm{g})$ of chicken in Ikom followed by $0.25 \mu \mathrm{g} / \mathrm{g}$ in kidneys of chickens in Etung and the lowest level was recorded in muscles $(0.12 \mu \mathrm{g} / \mathrm{g})$ of chicken in Odukpani. The high concentration value of $\mathrm{Pb}$ in liver and kidney showed that this toxic metal accumulates mostly in the liver where they are detoxified. These results confirm the findings of Akan et al. (2010) who observed $0.22 \mu \mathrm{g} / \mathrm{g}$ lead concentration in liver of chicken in rural area of Maiduguri, Nigeria. Mariam et al. (2004) reported higher levels of lead concentration in liver of poultry $(3.15 \mu \mathrm{g} / \mathrm{g})$ and kidney $(3.85 \mu \mathrm{g} / \mathrm{g})$. A higher lead concentration was observed by 
Table 2. Interactive effect of locations and heavy metals on concentration levels in tissues and organs.

\begin{tabular}{|c|c|c|c|c|c|c|c|c|}
\hline \multirow{2}{*}{$\begin{array}{l}\text { Heavy metal } \\
(\mu \mathrm{g} / \mathrm{g})\end{array}$} & Muscle & Liver & Kidney & Lungs & Muscle & Liver & Kidney & Lungs \\
\hline & \multicolumn{4}{|c|}{ Cocoa-producing area (Ikom) } & \multicolumn{4}{|c|}{ Non cocoa producing area } \\
\hline Cadmium & $0.09 \pm 0.05^{a}$ & $0.01 \pm 0.51^{a}$ & $0.06 \pm 0.43^{a}$ & $0.07 \pm 0.02^{a}$ & $0.03 \pm 0.01^{b}$ & $0.04 \pm 0.01^{b}$ & $0.03 \pm 0.01^{b}$ & $0.01 \pm 0.00^{b}$ \\
\hline Lead & $0.17 \pm 0.03^{a}$ & $0.17 \pm 0.09^{a}$ & $0.16 \pm 0.35^{a}$ & $0.14 \pm 0.18^{a}$ & $0.07 \pm 0.03^{b}$ & $0.08 \pm 0.02^{b}$ & $0.08 \pm 0.04^{b}$ & $0.06 \pm 0.0^{b}$ \\
\hline Mercury & $0.03 \pm 0.01$ & $0.03 \pm 0.01$ & $0.02 \pm 0.01$ & $0.01 \pm 0.00$ & $0.02 \pm 0.01$ & $0.02 \pm 0.01$ & $0.03 \pm 0.01$ & $0.02 \pm 0.01$ \\
\hline Chromium & $1.57 \pm 0.72^{a}$ & $1.79 \pm 1.22^{a}$ & $1.02 \pm 0.59^{a}$ & $1.67 \pm 0.56^{a}$ & $0.53 \pm 0.11^{b}$ & $0.67 \pm 0.12^{b}$ & $0.77 \pm 0.99^{b}$ & $0.61 \pm 0.04^{b}$ \\
\hline Arsenic & $0.03 \pm 0.01$ & $0.03 \pm 0.01$ & $0.02 \pm 0.01$ & $0.01 \pm 0.00$ & $0.02 \pm 0.01$ & $0.02 \pm 0.11$ & $0.02 \pm 0.00$ & $0.01 \pm 0.00$ \\
\hline \multirow[t]{2}{*}{ Nickel } & $1.08 \pm 0.62$ & $1.15 \pm 0.89$ & $1.08 \pm 0.80$ & $1.10 \pm 1.00$ & $1.12 \pm 0.08$ & $1.14 \pm 0.10$ & $1.12 \pm 0.93$ & $1.12 \pm 0.67$ \\
\hline & \multicolumn{3}{|c|}{ Cocoa-producing area(Etung) } & \multicolumn{5}{|c|}{ Non cocoa producing area } \\
\hline Cadmium & $0.09 \pm 0.05^{a}$ & $0.10 \pm 0.46^{a}$ & $0.90 \pm 0.05^{a}$ & $0.07 \pm 0.02^{a}$ & $0.03 \pm 0.01^{b}$ & $0.04 \pm 0.01^{b}$ & $0.03 \pm 0.01^{b}$ & $0.01 \pm 0.00^{b}$ \\
\hline Lead & $0.16 \pm 0.78^{a}$ & $0.17 \pm 0.06^{a}$ & $0.17 \pm 0.04^{a}$ & $0.15 \pm 0.06^{a}$ & $0.07 \pm 0.03^{b}$ & $0.08 \pm 0.02^{b}$ & $0.08 \pm 0.04^{b}$ & $0.06 \pm 0.02^{b}$ \\
\hline Mercury & $0.02 \pm 0.01$ & $0.03 \pm 0.01$ & $0.03 \pm 0.01$ & $0.01 \pm 0.01$ & $0.02 \pm 0.01$ & $0.02 \pm 0.01$ & $0.03 \pm 0.01$ & $0.02 \pm 0.01$ \\
\hline Chromium & $1.59 \pm 0.11^{\mathrm{a}}$ & $1.86 \pm 0.58^{a}$ & $1.62 \pm 0.74^{\mathrm{a}}$ & $1.72 \pm 0.90^{a}$ & $0.53 \pm 0.11^{b}$ & $0.67 \pm 0.12^{b}$ & $0.77 \pm 0.99^{b}$ & $0.61 \pm 0.04^{b}$ \\
\hline Arsenic & $0.03 \pm 0.01$ & $0.02 \pm 0.01$ & $0.03 \pm 0.01$ & $0.01 \pm 0.00$ & $0.02 \pm 0.01^{c}$ & $0.02 \pm 0.11$ & $0.02 \pm 0.00$ & $0.01 \pm 0.00$ \\
\hline
\end{tabular}

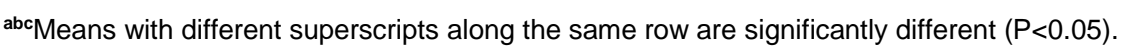

Spierenburg et al. (1988) in liver and kidney of cattle within a $20 \mathrm{~km}$ radius of Zinc refineries, compared to cattle in unpolluted controls areas. A higher concentration of lead than the permissible limit in liver and kidney of animal has been reported by Aranha (1994) and Danev et al. (1996). Furthermore, the authors indicated that $80 \%$ samples of liver and $100 \%$ samples of kidney were contaminated above the limits set by the country's regulations. Similarly, Maldonado et al. (1996) studied lead with reference to its intestinal absorption, mobilization and redistribution during lactation in rats and showed significantly higher levels of lead in livers and kidneys. Osuji and Onojake (2004) reported enhanced levels of nickel, copper and lead in soils of Niger Delta. This may result in absorption by plants, leading to possible bio-accumulation in animals that feed on them. All these metals may lead to toxic reaction along the food chain (Duffus 1980; Lawal et al., 2006; Okonya et al., 1988). These results revealed that $\mathrm{Pb}$ accumulated mostly in liver which agrees with reports of many studies (Miranda et al., 2005; Koréneková et al., 2002). High levels of $\mathrm{Pb}$ in poultry products possibly arise mainly from contamination of feed and water sources (Oforka et al., 2012). The major source of lead pollution is automobile exhaust gases which arise from anti-knocking agent added in gasoline resulting in soil contamination and plants (Mariam et al., 2004). Other sources are untreated waste effluents of industry, which find their way to irrigation channels and hence pollute the fodder through soil. Lead is a metabolic poison and a neurotoxin that binds to essential enzymes and several other cellular components and inactivates them (Cunning ham and Saigo, 1997). Toxic effects of lead are seen on haemopoietic, nervous, gastrointestinal and renal system (Baykov et al., 1996).

\section{Mercury (Hg)}

Mercury concentration as determined in tissue and organs of chicken at various locations of study are summarized in Tables 1 and 2 . Highest mercury concentration was found in kidney of chicken in $1 \mathrm{kom}(0.05 \mu \mathrm{g} / \mathrm{g})$ and lowest in the muscle $(0.01 \mu \mathrm{g} / \mathrm{g})$ tissue in chicken in Odukpani. All the study samples at different locations showed 
mercury concentration within 0.01 to $0.03 \mu \mathrm{g} / \mathrm{g}$ and are within the permissible limit of 0.03ppm (ANZFA, 2001). Samek et al. (1997) discovered the highest mercury quantity in skin and liver of chicks. Mariam et al. (2004) attributed a greater concentration of mercury in poultry to intake of mercury-contaminated feeds as compared to other animals. Key environmental sources of mercury include pesticide and fertilizer, contamination of stream, run-off water, rivers and lakes, industrial wastes and fungicides. The mercury escapes into the air and soil and get accumulated in fodder plant and hence in animal tissues. Mercury is toxic to central nervous system and the kidney is the organ most vulnerable to damage. The easy access to this toxicant to man is through multiple pathway - air, water, food, domestic products and even vaccines increases exposure (Harada, 2001). Children and foetus are more susceptible to mercury toxicity. According to WHO (2000) report, $0.05 \mathrm{mg} / \mathrm{kg}$ mercury contaminated food should not be sold for human consumption.

\section{Chromium (Cr)}

The concentration of chromium in tissue and organs of chicken significantly $(\mathrm{P}<0.05)$ differ between various study locations. Liver and kidney of chickens recorded higher $\mathrm{Cr}$ concentration than muscles and lungs from different locations. The highest $\mathrm{Cr}$ concentration was found in kidney $(2.11 \mu \mathrm{g} / \mathrm{g})$ of chicken in Etung Local Government Area (cocoa producing area) which may be attributed to pesticides, fungicide as well as fertilizer application in cocoa plantations. The concentration levels of $\mathrm{Cr}$ in this study were higher than $0.65 \mu \mathrm{g} / \mathrm{g}$ (liver) and $0.27 \mu \mathrm{g} / \mathrm{g}$ (kidney) in local chicken reported by Akan et al. (2010). Iwegbue et al. (2008) reported chromium concentration in chicken meat, gizzard and turkey to range between 0.01 and $3.43 \mathrm{mgkg}^{-1}$ which is above the permissible limit of $0.10 \mu \mathrm{g} / \mathrm{g}$ by FAO / WHO (2000). Chromium is an essential element assisting the body to utilize sugar, protein and fat, at the same time it is carcinogenic. It act as a co-factor in insulin hormone response, controlling carbohydrate metabolism in human. However, increased concentration of this metal can affect mineral and enzymes status of animal and human being. ATSDR (2004) pointed out that excessive amount of chromium may cause adverse health effects. The chromium concentration in the livers and kidneys of study samples is strikingly high and indicating chromium pollution in the environment. Chromium can be transported by surface run-off to surface water in its soluble form. Zhao et al. (2002) pointed out that soluble and unabsorbed chromium complexes can leach into soil solution which could make it more bioavailable for plant root absorption hence polluting the fodder through the soil. However, the leach ability also increases as the soil $\mathrm{pH}$ increases.

\section{Arsenic (As)}

The arsenic concentration was observed in the muscles and organs of chickens at different locations of study and it was found that kidney of local chicken in Etung (cocoa producing area) showed the highest concentration of 0.05 $\mu \mathrm{g} / \mathrm{g}$ and lowest concentration of $0.01 \mu \mathrm{g} / \mathrm{g}$ in the lungs of chickens in all study locations (Tables 1 and 2). The permissible limit of arsenic in the livers of chickens has been reported as $2.0 \mathrm{ppm}$ (ANZFA, 2001). But the results of this study showed that the arsenic concentration in all the samples studied were lower than $2.0 \mathrm{ppm}$. Higher concentration of arsenic in livers (78.96 ppm) and kidneys $(63.45 \mathrm{ppm})$ of poultry have been reported by Mariam et al. (2004). The results of this study is in line with the observations of Akan et al. (2010) who reported arsenic concentration levels of $0.03 \mu \mathrm{g} / \mathrm{g}$ in liver and 0.11 $\mu \mathrm{g} / \mathrm{g}$ in kidney of chickens. Higher concentration of arsenic in the livers and kidneys of cattle and goats has also been reported by Krupa and Swida (1997). Arsenic pollution in the environment may be due to copper smelting, coal combustion, burning of firewood and cow dung (Charles and Margaret, 1993). Furthermore, many arsenic compounds absorb strongly in soils and are transported only over short distances in ground water and surface water.

\section{Nickel (Ni)}

The concentration of nickel in the muscle, liver, kidney and lungs ranged between 1.00 and $1.16 \mu \mathrm{g} / \mathrm{g}$ in all the study locations. The highest nickel concentration of 1.16 $\mu \mathrm{g} / \mathrm{g}$ and $1.15 \mu \mathrm{g} / \mathrm{g}$ were observed in the lungs of chicken in Etung (cocoa area) and Odukpani (non-cocoa area) respectively, while the lowest value of $1.00 \mu \mathrm{g} / \mathrm{g}$ was found in the muscles of chicken in Odukpani. These results confirm the findings of Akan et al. (2010) who observed higher value of nickel in liver $(1.09 \mu \mathrm{g} / \mathrm{g})$ than that of kidney $(0.24 \mu \mathrm{g} / \mathrm{g})$ in chicken. Present results obtained for nickel in liver were in the line with that of Ghita et al. (2009) who also observed a higher concentrations of chromium, iron, zinc and nickel in liver and intestine than in muscles. Oforka et al. (2012) reported mean values of $0.08 \mathrm{mgkg}^{-1}, 0.167 \mathrm{mgkg}^{-1}$ and $0.74 \mathrm{mgkg}^{-1}$ nickel in gizzard, liver and muscles respectively. Concentration levels of nickel observed in this study were higher than the values stated above, but are similar to the results of similar study by Surtipanti et al. (2005) in Indonesia. The permissible limit of nickel in food according to WHO (1996) is $0.5 \mathrm{mgkg}^{-1}$. The results of the current study indicated higher nickel concentration in tissue and organs at different locations which exceeded the stipulated tolerance limit. This indicated nickel pollution/contamination in the study locations. This may be attributed to results from geological weathering, herbicides, and pesticides application and leaching of 
rocks as well as discharge of domestic wastes in these areas.

Table 2 shows the interactive effect of locations and heavy metal concentration on tissues and organs of local chicken. There was no significant $(P>0.05)$ interaction effects on mercury, arsenic and nickel concentrations in tissues and organs of chicken. Although, cocoa producing areas (lkom and Etung) exhibited higher concentration values of these metals than non-cocoa producing area. However, significant interaction $(P<0.05)$ of location and heavy metals (lead, cadmium, chromium) concentration was observed in the tissues and organs of chicken in both cocoa and non-cocoa producing areas.

\section{Conclusion}

This study was set out to evaluate the concentration and possible accumulation of heavy metals $(\mathrm{Cd}, \mathrm{Pb}, \mathrm{Hg}$, As and $\mathrm{Ni}$ ) in tissue/organs of family poultry (local chicken) in cocoa producing and non-producing areas of Cross River State. General results show that heavy metals accumulations were mostly higher in liver and kidney and lower in muscle and lungs and have concentrations below the permissible limits of FAO/WHO (2000) while the concentration of $\mathrm{Cr}$ and $\mathrm{Ni}$ in all study area were higher. The concentration level of metal studied in cocoa areas were below the permissible levels (FAO/WHO, 2000), thus chickens may be considered safe for human consumption from these areas. However, efforts should be made to reduce the presence of Chromium ( $\mathrm{Cr}$ ) and Nickel (Ni) in the environment to avoid its bioaccumulation and consequently its toxic effect. The information provided from this study may form or serve as guidelines and standards for chicken meat products in cocoa producing and non-producing areas of Nigeria.

\section{CONFLICT OF INTEREST}

The authors declare that they have no conflict of interest.

\section{REFERENCES}

Akan, J. C., Abdulrahman, F. I., Sodipo, O. A., \& Chiroma, Y. A. (2010). Distribution of Heavy metal in the liver, Kidney and meat of Beef, Mutton, caprine and hicken from Kasuwan Shanu Market in Maiduguri Metropolis Borno State, Nigeria. Res. J. of Applied sciences, Engineering and Technology, 2(8), $743-748$.

ANZFA (2001). (Australia New zealand and Food Authority). Wellington N Z. 6036 May, 2001. Retrieved from URL: http://www.Anzfa.Gov.all.

Aranha, K. (1994). Environmental Chemistry. $3^{\text {rd }}$ Edition, New Age International Ltd. Publisher, New Delhi, Pp. 213-219.

ATSDR (2004). Agency for Toxic substances and Diseases Registry, Division of Toxicology, Clifton Road, NE, Atlanta, Ga. Retrived from http://www.atsdr.cdc.gov.
Baykov, B. D., Stoyanov, M. P., \& Gugova, M. L. (1996). Cadmium and Lead Bioaccumulation in male chickens for high food concentrations. Toxical. Environmental Chemistry, $54,155-159$

Belton, P. S. (2006). Trace Element Analysis of Food and Diet RSC Food ANALYSIS MONOGRAPHS Royal society of chemistry, Thomas Graham House Science Park, Milton Road, Cambridge, CBLOWF, UK.

Charles, E., \& Margaret, C.H. (1993). Environmental science, $3^{\text {rd }}$ ed. Prentice - Hall Publishers, London, Pp. 258-263.

Cunning ham, W. P., \& Saigo, B. W. (1997) Environmental Science a Global concern. $4^{\text {th }}$ Edn., WMC Brown Publisher, New York, p. 389.

Danev, M., Serafimo vska, V., Sekulovski, P., Stojkovic, E., Kristic, B., \& Zoric, M (1996). Cadmium contamination of beef. Technol. Mesa, 37, 19-21.

Demirezen , D., \& Uruoc, K. (2006). Comparative study of trace elements in certain fish, meat andmeat product. Meat Science; 74, 255-260.

Doganoc, D. Z. (1996). Distribution of lead, cadmium and Zinc in tissues of hens and chicken from Sloeia. Bulletin of Environmental Contamination Toxicology, 57, 932-937.

Duncan, D. B. (1980). Multiple Range and Multiple F - test. Biometrics 11, 1-42.

FAO/WHO (2000). Report of the $32^{\text {nd }}$ session of the codex committee of the food additives contaminants. Beijing people's Republic of China, 20 - 24 March.

Ghita, M. V., Stanescu, L., Tudor, L. I., \& Gallis, A. M. (2009). Determination of heavy metals content of meat and meat by products by using neutron activation analysis and atomic absorption spectrometry. Scientific works - University of Agronomical Science and Veterinary Medicine, Bucharest Series C. Veterinary Medicine, 55(3),140-146

González-Weller, D., Karlsson, L., Caballero, A., Hernández, F., Gutiérrez, A., González-Iglesias, T., Marino M., \& Hardisson, A. (2006). Lead and cadmium in meat and meat products consumed by the population in Tenerife Island, Spain. Food additives and Contaminants, 23(8), 757-763.

Iwegbue, C. M. A, Nwajei, G. E, lyoha, E.N. (2008). Heavy metal residues of chicken meat and gizzard and turkey meat consumed in southern Nigeria. Bulg. J.vet.med.11(4), 275280.

John, H. H., \& Jean, I. R. (1994). Food Additives, Contaminants and Natural Toxins. In : Maurice Modern Nutrition in Health and Disease. $8^{\text {th }}$ Edn, part 11, Pp. 1597-1598.

Johnson, C. L. (2004). In the environment: sources, Toxicities and prevention of exposure, Predator Ann. 33(7), 437-442.

Koréneková, B., Skalieka, M., \& Nad, P. (2002) Concentration of some heavy metals in cattle reared in the vicinity of metallurgic Industry. Veterinarski Arhiv, 72(5), 259-267.

Krupa, J., \& Swida, J. (1997). Concentration of certain heavy metal in the muscles, liver and kidney of goats fattened in the Beiszczady mountains. Anim. Sci, 15, 55-59.

Lee, D. H., Lee, I. K., Song, K., steffes, M., Toscano, W., Baker, B. A., \& Jacobs, O. R. (2006). A strong Dose Response Relation Between serum concentrations of persistent Organic Pollutant and Diabetes care, 29, 1638-1644.

Magothe, T. M., Okeno, T. O., Muhuyi, W. B., \& Kahi, A. K. (2012) Indigenous chicken production in Kenya. Current status. World Poultry Science Journal, 68(11), 119-132.

Maldonado-Vega, M., Cerbon-Solorzano, J., Albores-Medina, A., Hernández-Luna, C., \& Calderon-Salinas, J. V. (1996). Lead: intestinal absorption and bone mobilization during lactation. Human \& experimental toxicology, 15(11), 872-877. 
Mariam, I., Igbal, S., \& Nagra, S. A. (2004). Distribution of some trace and macrominerials in beef, mutton and Poultry. Int. J. Agric Bio., 1(6), 816-820.

Miranda, M., Lopez-Alonso, M., Castillo, C., Hernández, J., \& Benedito, J. L. (2005). Effects of moderate pollution on toxic and trace metal levels in calves from a polluted area of northern Spain. Environment International, 31(4), 543-548.

Oforka, N. C., Osuji, L. C., \& Onwuachu, U. I. (2012). Assessment of Heavy metal pollution in muscle and internal organs of chickens raised in River State, Nigeria. Journal of Emerging Treads in Engineering and Applied Science, 3(3), 406-411.

Osuji, L., \& Onojake, C. M (2004). Trace heavy metals associated with crude oil: a case study Ebocha - 8 oil - spill polluted site in Niger Delta, Nigeria. Chemistry and Biodiversity, 1, 1708- 1715.

Roga-Franc, M., Kosla, T., \& Rokicki, E. (1996). Cadmium concentration in organs of dairy cows depending on that element meadow cover. Mengen Spurenelem, Arbeistag, Pp. 393-397.

Samek, M., Zarski, T. P., \& Debski, B. (1997). Distribution of mercury in the tissue of broiler chicken after Agronal Poisoning, Vet. Med, 20, 101-106.
Spierenburg, T. J., De-Graaf, G. J., \& Braars, A. J. (1988). Cadmium, Zinc, Lead and Copper in livers and kidney of cattle in the neighborhood of Zinc refineries. Environ. Monit. Asses. 11, 107-114.

Stoyke, M., Doberschutz, K. D., \& Lusky, K. (1995). Heavy metal contents (cadmium, lead and mercury) in selected feedstuffs, organs and tissue in cattle from different sites of Brandenburg. Mengen - Spurenelen.. Arbeitstag, Pp. 269276.

Surtipanti, S., Suwirma, S., Yumiarti, S., \& Mellawati, Y. (1995). Determination of Heavy Metals in Meat, Intestine, Liver, Eggs, and Chicken Using Neutron Activation Analysis and Atomic Absorption Spectrometry. Atom Indonesia, 21(1), 1-8.

WHO (1996). World Health Organisation : Health critenia and other supporting information. In Guidelines for drinking water quality Vol 2, $2^{\text {nd }}$ edu, Geneva. Pp. 31-38.

Zarski, T. P., Zarska, H., Samek, M, and Siluk, I (1997). Mercury contamination of the tissues of cattle from various regions of Poland. Vet. Med, 20, 107-111. 